\title{
Intrauterine device perforation symptomatic after nine years
}

\author{
Dokuz yıl sonra semptomatik olan rahim içi araç perforasyonu olgusu
}

Ayse Filiz Gökmen Karasu, Mustafa Maraşı, IInur Adanır, Mehriban Aliyeva

Bezmialem Vakıf Üniversitesi Tıp Fakültesi, Kadın Hastalıkları ve Doğum ABD, Istanbul

\begin{abstract}
Intrauterine device (IUD) is a cost effective, long acting and reversible method of contraception. We present a patient who had an IUD inserted nine years prior to attending our clinic; complaining of vaginal discharge and hematuria. The threads of the device were observed at the external cervical os however the transvaginal ultrasonography we performed as part of a routine work-up revealed that the device had perforated the entire body of the myometrium. We suspected bladder injury and for further diagnostic information MRI was utilized. MRI showed bladder serosa involvement. We were able to retrieve the IUD with the aid of a hysteroscopic forceps. Cystoscopy was performed after the procedure and there was no intraluminal bladder pathology. We cannot verify the cause of the uterine perforation; however we believe that IUD's should be adminestered by experienced providers without prior blunt sounding instrumentation in order to decrease uterine perforations. We suggest that transvaginal ultrasound should routinely be performed on women who present for their gynecological visit. This is especialy important for patients who chose to use a IUD for contraception.
\end{abstract}

Pam Med J 2017;10(2):196-198

Key words: Intrauterin Devices, IUD perforation, family planning, contraception.

\section{Özet}

Rahim içi araç (RIA) uzun etkili geri dönüşümlü ve maliyet etkinliği kanıtlanmış bir kontrasepsiyon yöntemidir. Dokuz yı önce RiA takılma öyküsü olan ve kliniğimize vajinal akıntı ve hematüri yakınmasıyla başvuran bir olguyu sunuyoruz. RİA ipleri spekulum muayenesinde izlendi ancak rutin olarak uygulanan transvajinal ultrasonografide RİA'nın uterus duvarını tamamen perfore ettiği görüldü. Mesane hasarından şüphelenildiği için çekilen MR'da RİA'nın transvers kolunun mesane serozasına kadar perforasyona yol açtığı rapor edildi. RIA histeroskopik forseps yardımıyla tek parça halinde çıkartıldı. İşlemin ardından sistoskopi uygulandı ve mesanede intraluminal patoloji izlenmedi. Bu vakada uterus perforasyonuna sebep olan faktörü belirleyemesek de; perforasyon komplikasyonunu azaltmak için RIAA uygulamasının deneyimli sağlık personeli tarafından ve işlem öncesinde keskin alet kullanılmadan yapılması gerektiğini düşünüyoruz. Rahim içi araç kullanan ve şikayeti olmayan sağlıklı hastalar başta olmak üzere rutin jinekolojik muayene için başvuran her kadına transvajinal pelvik ultrasonografi uygulanmasını öneriyoruz.

Pam Tıp Derg 2017;(2):196-198

Anahtar sözcükler: Rahim içi Araç, RİA perforasyonu, aile planlaması, kontrasepsiyon.

\section{Introduction}

Intrauterin devices are favourable reversible contaceptive methods requiring minimal maintenance by women. They are cost effective and it is estimated that 150 million women use it worldwide [1]. An infrequent but noteworthy complication is that of uterine perforation. The incidence of intrauterine device perforation risk is stated as $0.03-0.08$ per 1000 insertions in the literature $[2,3]$.

\section{Case Report}

Multigravid 31 year old woman complaining of vaginal discharge and hematuria for the last two weeks attended our outpatient clinic. Her medical history was unremarkable. She had two vaginal deliveries and her menstrual cycles were regular. Nine months postpartum she had an IUD (intrauterine device) inserted without difficulty which was 9 years ago. She was breastfeeding at the time and continued to

Ayşe Filiz Gökmen Karasu

Yazışma Adresi:Bezmialem Vakıf Üniversitesi Tıp Fakültesi, Kadın Hastalıkları ve Doğum ABD,İstanbul e-mail:afgokmen@gmail.com

Gönderilme tarihi: 21.06.2016

Kabul tarihi: 16.11.2016 
do so for 3 years. She had no other complaints. Her last pelvic exam was a year ago and she declared that her IUD was also checked but she never received a pelvic ultrasound examination. Upon placing the speculum; strings of the IUD were noted. The uterus was palpated as anteverted anteflexed by bimanual uterine examination and there was no motion tenderness. Transvaginal ultrasonography was performed as part of the routine gynecological work-up. IUD was observed to be perforating the entire length of the myometrium above the level of the internal cervical os with close proximity to the bladder (Figure 1). In order to obtain more diagnostic information MRI was ordered. The report certified the perforation of the IUD through the myometrium with the tip of the device embedded in the bladder serosa. Prevesical fat planes were preserved with the absence of intraluminal pathology concerning the bladder.

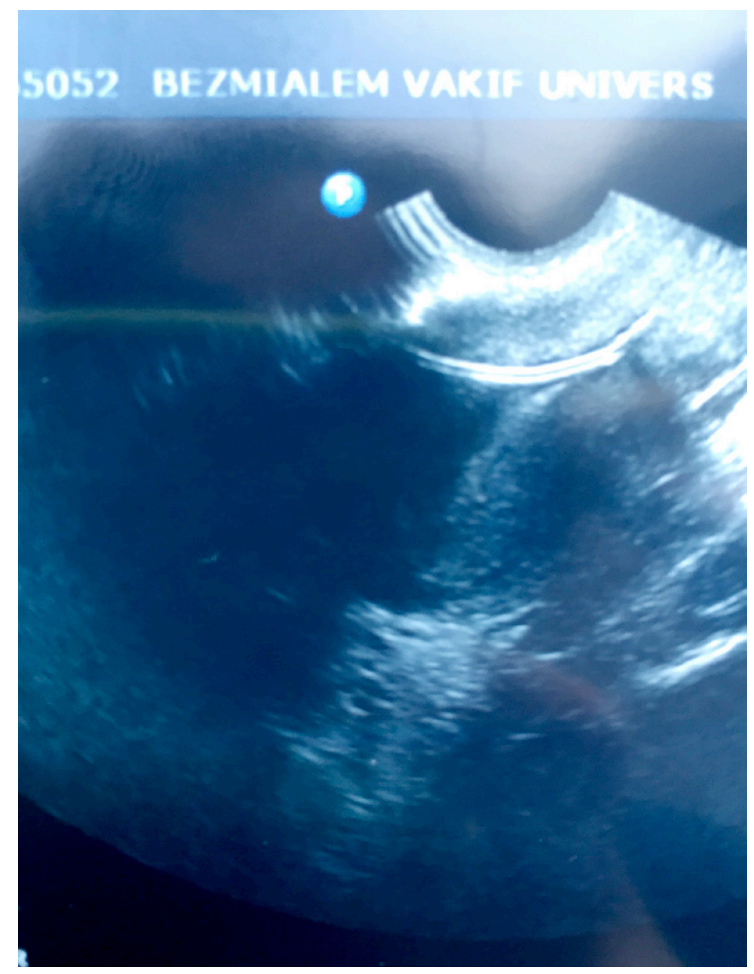

Figure 1. Transvaginal ultrasonography image. Intrauterine device is observed to be perforating the entire body of the myometrium with close proximity to the bladder.

Pulling the threads of the device under general anesthesia was attempted without success. Next a hysteroscope was introduced and the endometrial cavity was visualized. One of the transverse arms of the device was embedded at the uterine wall. Hysteroscopic forceps was utilized in a rotating and pulling action to retrieve the device in one piece. Cystoscopy was performed. Cystoscopic findings were insignificant other than minimal edema which was observed at the posterior wall of the bladder adjacent to the perforation.

\section{Discussion}

Uterine perforation is a rare but potentially disastrous complication of IUD use. Lack of experience, improper technique, use of blunt instrumentation, application of excessive force and anatomic factors such as a stenotic cervix have all been suggested as contribituve factors. The perforation may be primary (at the time of insertion) or secondary. Secondary perforation may be due to uterine contractions, a malpositioned IUD or an uterine anomaly. IUD's are usually adminestered without general anesthesia therefore pain associated with the procedure may be overlooked by the physician. Additionally Andersson et al reported that IUD insertion in lactating women was associated with less pain possibly due to circulating elevated endorphin levels and a perforation leading to pain would be more tolerable [4]. Zakin and co-workers have reported that intraabdominal visceral organs were injured in $15 \%$ of IUD perforation cases [5]. Duration between device insertion and symptoms of bladder perforation may vary from 6 months to 16 years [6]. Our patient had her IUD inserted nine years ago and her hematuria complaint was present for only the last fortnight. Ignored symptoms may lead to total bladder perforation. In our case the perforation was limited to the serosal layer of the bladder therefore simple hysteroscopic retrieval was sufficient and no other approach was needed.

Upon speculum observation; absence of IUD threads at the external cervical os should alarm the examining healthcare worker about a possible complication and further diagnostic testing should be performed. The ideal diagnostic modality would be to perform a transvaginal ultrasonography which would demonstrate the endometrial cavity and the presence or absence of an IUD. The IUD may have dislocated to the myometrium or perforated nearby structures. Intravesical involvement may easily be demonstrated if the patient's bladder is slightly full. However like our aforementioned 
case existence of the device strings does not rule out the possibility of a perforated uterus. We believe that transvaginal ultrasound should routinely be performed on women who present for their gynecological visit. This is especialy important for patients who chose to use a IUD for contraception.

IUD's are generaly considered a safe and effective form of contraception and perforation risk less than 1 in 1000 insertions is acceptable. Women desiring this method of contraception should be allowed access and appropiate referrals should be made. We cannot verify the cause of the uterine perforation; however we believe that IUD's should be adminestered by experienced providers without prior blunt sounding instrumentation in order to decrease uterine perforations.

Conflict of Interest Statement The authors declare no conflict of interest.

\section{References}

1. D'Arcangues C. Worldwide use of intrauterine devices for contraception. Contraception 2007;75:2-7.

2. Markovitch $O$, Klein Z, Gidoni $Y$, Holzinger M, Beyth Y. Extrauterine mislocated IUD: is surgical removal mandatory? Contraception 2002;66:105-108.

3. Ozgun MT, Batukan C, Serin IS, Ozcelik B, Basbug M, Dolanbay M. Surgical management of intra-abdominal mislocated intrauterine devices. Contraception 2007;75:96-100

4. Andersson K,Ryde-Blomqvist E, Lindell K, Odlind V, Milsom I. Perforations with intrauterine devices. Report from a Swedish survey. Contraception 1998;57:251253.

5. Zakin D, Stern WZ, Rosenblatt T. Complete and partial uterine perforation and embedding following insertion of intrauterine devices. Classification, complications, mechanism, incidence, and missing string. Obstet Gynecol Surv 1981;36:335-353.

6. Dietrick DD, Issa MM, Kabalin JN, Bassett JB. Intravesical migration of intrauterine device. J Urol 1992;147:132134. 